\title{
The Effect of Using Writer's Workshop Approach on Developing Basic Writing Skills (Mechanics of Writing) of Prospective Teachers of English in Egypt
}

\author{
Ashraf Atta M. S. Salem ${ }^{1}$ \\ ${ }^{1} \mathrm{PhD}$ in TEFL, Institute of Educational Studies \& Researches, Cairo University, Egypt \\ Correspondence: Ashraf Atta M. S. Salem, State of Kuwait, Mahboula, Block 1, Street 131, Building 24, behind \\ Alhashel Complex. E-mail: sirashrafams@hotmail.com
}

Received: May 4, 2013 Accepted: May 20, 2013 Online Published: June 3, 2013

doi:10.5539/elt.v6n7p33 URL: http://dx.doi.org/10.5539/elt.v6n7p33

\begin{abstract}
The present study aimed at investigating the effects of using a program based on the writing workshop approach on developing basic writing skills of prospective teachers of English in Hurgada faculty of Education. For that purpose, the researcher constructed and validated a teaching program based on the writing workshop approach, checklist of the skills and subskills of basic writing skills, and pre-posttest of basic writing skills. The sample of the study was forty students in Hurgada faculty of Education, English Division (prospective teachers of English). They were randomly chosen and assigned to an experimental group. The experimental group students were taught writing using the writing workshop approach after they had basic writing skills pretest. Findings of the study indicated the writing workshop-based program had significant effects on improving the subjects' basic writing skills.
\end{abstract}

Keywords: Writer's Workshop, Mechanics of writing, prospective teachers of English

\section{Introduction}

\subsection{Introduction of the Problem}

Writing as one of the four basic language skills, is given a unique importance. The value of writing is confirmed by research. That shows its value for academic as well as occupational purposes. Writing is a valuable tool for communicating one's thoughts to others. It helps to both promote the sense of ownership and express his inner feelings. Writing is the commonest way of assessing students' performance in English especially in the Arab countries (Salem, 2008).

Al-Saleem (2008: 77) emphasizes that writing is an essential component of classroom activities as it reinforces grammatical structures and vocabulary. He also adds that writing helps students to express themselves and provide their ideas without being pressured by face-to-face communication. This was affirmed by Helal (2003: 18) who states that challenging writing activities add variety to writing instruction and develop writing instruction and develop important literacy skills.

In spite of its ultimate importance, writing is one of the most difficult to master language skills. Heaton (1994: 7) assumes that the writing skills are complex and sometimes difficult to teach, requiring mastery not only of grammatical and rhetorical devices but also of conceptual and judgmental elements. The writing process includes many and varied skills necessary for writing well prose such as; language use, mechanical skills, treatment of content, stylistic skills and judgmental skills. EFL learner is in a bad need to develop his writing skills as a tool to foster the understanding of other language skills. Speaking and listening skills are easier to be acquired-through conversation- than writing and reading.

Richards (1990: 101-2) observes that whereas the rules of spoken discourse are acquired through conversation and do not require instruction, the rules of written discourse are largely learned through instruction and practice. The fact that written discourse reflects certain different rules from spoken language may account for difficulties learners have in mastering the ability to write well. For some time, under the influence of the audio-lingual approach to language teaching, speech has been regarded as being of primary importance, with writing being placed a poor second. Writing now is no longer relegated to second place. Instead, writing is given its own status 
in the ELT course. There are a number of reasons for this. For one thing, linguists have become interested in studying the characteristics of written as well as spoken language, and it is now clear to everyone that writing is not simply a poor relative of speaking - or that speaking is merely a sloppy version of writing. For another, there has been an increasing concern with the need to teach writing since it is a useful tool for practice exercises and reinforcement of academic skills. Writing itself has primary value as a language teaching tool (Abolyosr, 1996: $15)$.

Research into writing in English as a second or a foreign language has shown that writing is much more than the production of graphic symbols. These symbols have to be arranged according to certain conventions to form words, and words have to be arranged to form sentences. Writing, in Byrne's words, is "the production of sequences of sentences arranged in particular order and linked together in certain ways (Byrne, 1993).

Writing workshop is student- centered approach to teach writing in a social context. Students learn in an environment that employs modeling and coaching where the teacher is a guide and facilitator of students learning .Typically, there is a mini-lesson at the beginning followed by stages of writing and rewriting after which students come to a sharing time to celebrate their work (El Said, 2006: 17). Aly (2002: 131) concurs that writing Workshop is an approach to writing where students spend larger time engaged in compositions and select topics of personal relevance. In a writing workshop, writing is also guided through many social activities that require students to explain their ideas, develop their thoughts, or even defend theirs before the teacher and their colleagues.

Strech (1994: 2) viewed that writing workshop is an approach that encourages students to become involved in the writing process by using their own topics and writing for their own reasons. A history of writing pedagogy shows that educators have recently moved from a skills based approach of teaching writing to a process based approach: teachers are now interested in showing how a piece of writing improves as the author consults with his or her instructor and peer.

Kieczykowski (1996), states that teachers who have incorporated daily writing workshop into their curricula have note the following significant benefits; First of all, using writer's workshop increasesself- esteem since writing workshop is totally initialized, all children are validated for their effects. All children are viewed as authors with important stories to tell. Second, it leads to student empowerment as students, not teachers, are taught to complement one another with specific praise and are encouraged to celebrate one another's success. They come more responsible for their own learning because they are charged with being positive critics. To do this student must listen attentively to peer sharing, as well as to mini-lessons and writing goals taught in the classroom. Third, writer's workshops provide risk - free environment as students are encouraged to write freely, using temporary or invented spelling. The emphasis is on content form and mechanics become secondary. Fourth, it helps them to enhance their phonemic awareness. Phonics, as it relates to reading and writing, is given an authentic setting during writer's workshop. Invented spelling is phonics in action. Students' reading of their own invented spellings further reinforces the phonetic process. Fifth, it Increases Fluency in Reading and writing. Early writers become more fluent in classrooms where writer's workshop occurs because they are given opportunities to publish their own words. Ownership becomes the vehicle for fluency, because they witness the fact that writing is really nothing more than thoughts, observations, or conversations written down. Finally, it provides Opportunities for development of oral and written language conversation.Therefore, Elizabeth (2004: 295) affirmed that whatever is written once remains forever; unless it is destroyed. She also confirmed that without the writing aspect, learning of a language remains incomplete.

\subsection{The Importance of the Problem}

The researcher noticed that student teachers of English lack the basic writing skills. They seek to convey all the information of the text without making use of the necessary basic skills for this process. So, the researcher tries to investigate the effectiveness of a proposed program based on using writing workshops in writing for developing basic skills needed for these students.

Prospective teachers of English suffer greatly when they are asked to achieve a writing task. This is manifested in their written pieces in the pilot study as it is clear that they lack the fundamental writing skills. This is the reason which makes them reluctant to write in English even it is vital to achieve tasks they need in the everyday life.

Students of the English Department at the Faculty of Education need writing for many reasons. For one thing, as undergraduates they need to write term papers and articles in English. They are asked to answer essay questions in different subjects such as novel, drama, poetry, etc. For another, they need to take notes in English at lectures, talks and when reading. Finally, as prospective teachers they need to write lesson plans, summaries, reports, 
short pieces of narrative, simplification of a passage to suit learners of a certain level, etc.

\subsubsection{Questions of the Study}

The present study tries to answer the following main question:

What is the effectiveness of using workshops in developing basic skills of writing for the third year primary stage prospective teachers of English?

1.2.2 Hypotheses of the Study

The current study tries to answer the following hypotheses:

1. There is a statistically significant difference between the mean scores of the experimental group on the basic writing skills pre-test and post-test in favour of the posttest.

2. There is a statistically significant difference between the mean scores of the experimental group on the process writing pre-test and post-test in favour of the posttest.

3. There is a statistically significant difference between the mean scores of the experimental group on the punctuation pre-test and post-test in favour of the posttest.

4. There is a statistically significant difference between the mean scores of the experimental group on the spelling pre-test and post-test in favour of the posttest.

\subsubsection{Significance of the Study}

This study is of special importance for the primary stage prospective teachers of English for the following considerations:

a. The study provides third year prospective teachers of English with practical guidelines for their present and future study.

b. The significance of the study also stems from the broad aim of facilitating writing process in English which these students are apt to encounter during their study-years (literature, linguistics, methods of teaching English etc.) in a way that enhances their study skills.

c. 3-The study helps primary stage prospective teachers of English establish the right writing habits in order to teach them appropriately to their future students.

d. It is also hoped that this program will be a step in the development of training courses for teaching other writing skills to primary stage prospective teachers of English at the faculties of Education.

\subsubsection{Delimitations of the Study}

The study is limited to measuring the effectiveness of using workshops in developing the basic writing skills of primary stage prospective teachers of English.

The skills treated in the present study are the basic writing skills and their sub-skills agreed upon by specialized jury members. The instructional time of the program devoted for the experimental group lasts for eight weeks, two meeting a week, two hours a meeting.

\subsubsection{Definition of Terms}

\subsubsection{The Writing Skills}

Mahran (2000:7) defined the writing skill as "the ability of producing the language in writing intelligibly, easily, expertly and well."

In the present study, the writing skill is defined as the ability to express oneself through writing in an organized and intelligible way producing sufficient content and using suitable words, correct structures, and proper conventions.

\subsubsection{The Writing Workshop}

El Said (2006:12) defined writing workshop as a student-centered approach to teaching writing in a social context. Students learn in an environment that employs modeling and coaching where the teacher is a guide and facilitator of students' learning. Typically, there is a mini-lesson at the beginning followed by stages of writing and rewriting after which students come to a sharing time to celebrate their work.

Massengill-McLeod (2001:15) defined the writing workshop as "an organizational approach to writing in the classroom that supports the recursive nature of writing by adapting a process approach."

Pollington (1999: 120) stated that "writing workshop is a process-based approach to writing instruction; typically student-driven, it emphasizes all stages of the writing process, encourages student autonomy, and teaches 
conventions in the context of [the] student's own writing."

Harris and Hodges (1995: 284) defined the writers' workshop as "a block of school time devoted to student planning drafting, and editing compositions for publication, often involving peer collaboration."

For the present study, the researcher defines writer's workshop as a process-based approach for teaching writing in a meaningful environment. It helps to teach writing in a social context. Students enjoy celebrating their work with others- in an author's chair- after modeling, peer conferencing and tender teacher guidance. Ideally, a writer's workshop begins with a mini-lesson followed by actual writing time and finally a celebration with the final product.

This definition highlights:

1. The active role of the learner as the focus of learning.

2. The role of the teacher as a guide and a facilitator.

3. The social nature of writing.

4. The recursive rather than the linear nature of the writing process.

\subsection{Relevant Scholarship}

Many studies were conducted to investigate the effect of using writer's workshop on developing writing skills. One of these studies was conducted by Coleman (2000as cited in El Said, 2006). It tries to investigate the effect of implementing the writer's workshop approach in a primary grade classroom. Results indicated that students responded positively to the implementation of a writer's workshop and their writing skills improved.

Aly (2002as cited in El Said, 2006) conducted a study to investigate the effect of using the writing workshop approach on developing student teachers' composing skills at the English department, Faculty of Education, Ain Shams University. The findings of the study showed that the writing workshop approach helps the students to improve their writing in terms of the writing production skills, i.e. content/organization styles, usage and mechanics. So this study is similar to the present study in the aims and sample yet they are different as the present study aimed at developing basic writing skills whereas Aly's study dealt with composing skills in general. Also, the present study was done in Upper Egypt whereas in Ain Shams university.

Another study was conducted by Agesilas (2003) to test the effectiveness of the writing workshop model in improving English-as-a-second-language (ESL) college students' writing skills. Results showed that the students acknowledged that the writing workshop had helped them to better understand the writing process. Students perceived classroom environment, peer response, collaborative writing and speaking as components that helped them the most in improving their writing skills.

In addition, El Said (2006) conducted a study to investigate the effects of using a program based on the writing workshop approach on developing the writing skills and minimizing the writing apprehension of second-year prep students in Upper Egypt. Results indicated that the writing workshop-based program had significant effects on improving the subjects' knowledge of writing skills, upgrading their writing performance, and minimizing their writing apprehension as compared to the control group student.

A review of researches on writing workshops suggests several conclusions. First, there is adequate evidence to support the assertion that the teaching of the writing process is a valuable practice. While the writing process is the actual material to be taught, the writing workshop can be viewed as a way of approaching the task of teaching writing and organizing it, feel confident and be initiative. Secondly, the establishment of the writing workshop can take risk in front of their teachers since there is no prescribed sequence for teaching skills and strategies. Thirdly, the abundance of qualitative research (and lack of quantitative research) is due to the nature of the topic studied. The cyclical nature of the writing process and the writing research approach parallels the dynamic characteristic of qualitative research. Lately, writing workshops, when implemented in their ideal form, take a large portion of the instructional day.

Primary stage prospective teachers of English need to develop their basic writing skills in general. This is due to three main reasons; first, they are prospective teachers of English so that they may teach their pupils how to write paragraphs and essays. Secondly, they need to take tests in other subjects like novels, poetry and drama so they need to write essays correctly. Thirdly, they are to be divided in their third year so it is a must to develop their writing skills in their third and fourth year. They have only two years of actual English study. Writing workshop is a student-centered approach rather than a teacher-centered approach. So, it can achieve good results when used in class in teaching writing. 
The results of the pilot study (conducted by the researcher and validated by a jury) showed a very low level in writing and a need for training in basic writing skills in particular. To the knowledge of the researcher, as yet no detailed research findings are available about basic writing skills of the primary stage prospective teachers of English.

The Ministry of Education conducted some short-term programs for training primary stage teachers of English. But this is not a comprehensive solution for the problem. A basic writing skills program is needed to develop the basic writing skills for the prospective teachers of English of the primary stage.

Accordingly student-teachers lack the necessary writing skills. This was manifested through the pilot study and the observations of the researcher. A need is urgent for training programs to develop these skills.

\section{Method}

\subsection{Experimental Design}

\subsubsection{The experimental Design}

The researcher made use of the quasi-experimental design. Thus, one group pre-posttest design was utilized in the experiment. The study sample was randomly chosen and assigned to one group from amongst the population of third year primary stage prospective teachers of English in Hurgada faculty of Education. The subjects of the study studied the new program after they were pretested. At the end of the experiment, the basic writing test was administered. This design can be depicted as follows:

\section{Pretesting $\longrightarrow$ Treatment $\longrightarrow$ Posttesting}

Figure 1. The experimental Design

\subsubsection{Variables of the Experiment}

A. The independent variable:

The writing workshop program

B. The dependent variables:

The performance of the prospective teachers of English concerning the basic writing skills.

\subsubsection{Instruments of the Study}

1. A checklist to determine the skills and sub skills of the writing process, (prepared by the researcher).

2. A pre-posttest on basic writing skills knowledge and performance, (prepared by the researcher).

3. The training program.

\subsection{Participants (Subjects) Characteristics}

The population of this study was third year primary stage prospective teachers of English at Hurgada faculty of Education. They studied English as a subject for eight years beginning in fourth-year primary.

The third year primary stage prospective teachers of English, Hurgada Faculty of Education were chosen for experimentation for the following considerations:

a) The third year primary stage prospective teachers of English, Hurgada Faculty of Education are still studying in the faculty of Education so they will benefit from the program in their university study. They are studying Literature (novel, drama and poetry) and also TEFL methodology in English and they need to write well in English. Therefore, a program in writing will help them greatly to develop their writing skills.

b) As they are students-teachers they are practicing teaching in their university year's study, so they may use the skills they acquired to develop their pupils writing skills.

c) Also they are going to graduate and to work in the field of teaching English. Therefore, their pupils at schools may benefit from the skills they will acquire in the new writing program.

\subsection{Sampling Procedures}

The researcher has selected the sample of the study randomly paying attention to the following criteria:

\subsubsection{The Drop-Outs}

The following students were excluded from the data analysis: 
a) Students who were too old.

b) Students who were absent in one or more of the tests included in the study.

\subsubsection{Homogeneity of the Experimental Group}

To achieve homogeneity of the experimental group, the following variables were controlled:

\subsubsection{Age}

The ages of the students were obtained from the faculty records, calculated and counted in months. Days less than fifteen were omitted. Fifteen days or more were counted a month. Thus, excluding too old, the ages of the students ranged from twenty to twenty one years.

\subsubsection{Socio-Economic Background}

The subject of the study represented the majority of the inhabitants of the area in which the study was conducted and they reflected the same socio-economic background of that area.

\subsubsection{Teacher}

The subjects were taught by the same teacher rather than the researcher so as to eliminate the subjectivity of the researcher.

\subsection{Sample Size, Power, and Precision}

The sample of the study consisted of forty students which were randomly chosen from the amongst the students in Hurgada faculty of Education. The number of students was forty students. The students chosen from Hurgada faculty of Education on the basis of their geographical residency alone regardless of their achievement level or socio-economic background.

\subsection{Measures and Covariates}

The researcher designed the basic writing pre-posttest in order to measure the effectiveness of writer's workshop in developing basic writing skills.

\subsubsection{Aim of the Test}

The aim of the test was to assess the effect of the writing workshop approach on developing third year primary stage prospective teachers of English knowledge/performance of the basic writing skills. More specifically, the test was used to compare knowledge of writing skills of the subjects of the study who were taught writing utilizing the writing workshop approach in the pre and post testing.

\subsubsection{Description of the Test}

The test was divided into four parts as follows:

Part (1): Writing workshop \& writing process.

$$
\text { Part (2): Punctuation. }
$$

Part (3): Spelling.

Part (4): Grammar.

These parts represented the core of the program. Designing the test was based on reviewing pertinent viewpoints of EFL specialists and reviewing related literature.

\subsubsection{Validity of the Pre-Post Test}

To judge the validity of the writing performance test, the researcher used two ways.

1. Validity by Jury Members

The test was submitted to a jury to decide on:

1. Clarity of test instructions.

2. Suitability of test items for assessing the basic writing skills of the third year primary stage prospective teachers of English students.

3. Suitability of test items for the third year primary stage prospective teachers of English students' level.

4. Suitability of the proposed scoring technique.

5. Any other comments or suggestions.

Some modifications were made in the wording of the test instructions in the light of the jury members' comments especially in those who have a psychological background.

The jury members decided that the test is generally valid to be used in assessing the third year primary stage 
prospective teachers of English's basic writing skills.

\section{Internal Consistency Validity}

The researcher used the correlation coefficients between the marks of every part of the four parts that constitute the test in order to determine the validity of the test.

Table 1. Internal Consistency Validity of the Pre-post Test of Writing Skills

\begin{tabular}{lllll}
\hline & First Question & Second Question & Third Question & Fourth Question \\
\hline The First Part & 0.651 & & & \\
\hline The Second Part & 0.753 & 0.518 & & \\
\hline The Third Part & 0.579 & 0.541 & 0.628 & 0.736 \\
\hline The Fourth Part & 0.729 & 0.681 & 0.719 & \\
\hline
\end{tabular}

As shown in table 1 correlation coefficients between the four parts of the test as well as the overall mark that these correlations are statistically significant at level 0.01 .

\subsubsection{Reliability of the Test}

The researcher used the inter-rater reliability to determine the reliability of the test. Two ratersparticipated in scoring the paragraphs written by students participating in the study (each rater was given a separate copy of the test papers to score by himself) after they were instructed in scoring paragraphs using the scoring criteria. Scores given by the two raters were correlated using Pearson Formula. The correlation coefficient between the first and second rater is (0.943) at significance level (0.01).

The researcher also used the Split-half way in order to determine the reliability of the test. Guttmann Formula which does not hypothesize that every part of the test is not equivalent to the other parts- was used to calculate the reliability of the test. The test reliability coefficient was $(0.85)$ at significance level $(0.01)$. Also, the researcher used Spearman-Brown Formula to determine the reliability of the test. The correlation coefficient between the score of the students for the single and double item within the test is (0.945). It is clear then that the test is reliable.

\subsubsection{Administration Time of the Test}

In calculating the time required for answering the test, the researcher recorded down the time each student in the pilot study finished answering the test. Then, time periods were averaged for the whole pilot sample. The calculated mean time was 120 minutes.

\subsection{Experimental Manipulations or Intervention}

The program aimed at developing the basic writing skills and writing conventions for the third year primary stage prospective teachers of English. It was based on the writing workshop approach. This constituted an attempt at changing the traditional teaching/learning environment of writing instruction that resulted in poor writing performance of the third year primary stage prospective teachers of English, , Hurgada Faculty of Education which, by turn, hindered the development of their writing skills. Based on this general aim of the program, the general objectives related to the units in the program were determined. These general objectives were as follows:

a) Developing the students' ability to practice the stages of writing (process of writing).

b) Developing the students' ability to use punctuation rules correctly.

c) Developing the students' ability to write without misspellings.

d) Developing the students' ability to use grammatical rules correctly

3.6.1 Steps of Designing the Program

In designing the program, the following steps were followed:

a. Defining objectives of the program. The behavioral objectives of the program were defined in the light of the previously defined subskills of basic writing. General objectives related to each unit as well as specific objectives of every lesson were defined. Taken into consideration was the inclusion of the three types of behavioral objectives - affective, cognitive and psychomotor - into each lesson. 
b. Identifying the basic writing subskills. The skills writing sub-skills that are necessary to upgrade the writing ability of the third year primary stage prospective teachers of English, Hurgada Faculty of Education were identified. For this purpose, a review of related literature was undertaken, including previous studies dealing with writing pedagogy, the course assigned for the third year primary stage prospective teachers of English, Hurgada Faculty of Education by the faculty of Education, the viewpoints of some EFL specialists (university professors, lecturers and instructors), as well as course descriptions of some writing syllabi. As a result, the following subskills were identified:

a) Producing sentences using correct punctuation:

- Eliminating run-on sentences.

- Eliminating sentence fragments.

- Eliminating rambling sentences.

b) Producing sentences without misspellings:

- Using suffixes.

- Using prefixes.

- Using roots.

- Using homophones, homonyms and homographs.

c) Using different stages of writing (process of writing).

d) Using grammar correctly while writing.

\section{Results}

Results of the study showed the usefulness of using the writer's workshop approach on developing the basic writing skills (mechanics of writing).

\subsection{Recruitment}

To administer the experiment of the study, the researcher followed these steps:

1. An introductory meeting was held with the subjects of the study in which they were given a general idea about the program as well as a timetable of the sessions. This was on February 20, 2012.

2. Actual teaching of the program began on March 2, 2012 and ended on May 4, 2012. Teaching took place two sessions a week. Every session took two hours, one session took place on Sunday and the other took place on Wednesday.

3. On February 24, 2012, the pretest in writing was administered to the sample of the study.

4. On May 2, 2012, the posttest in writing was administered to the subjects of the study.

This was the final day of administering the program.

\subsection{Statistics and Data Analysis}

The Statistical Package for Social Sciences (SPSS, version 17.0) was used in the treatment of the results of the study. T-test formula was employed in analyzing students' scores on the basic writing skills test.

Conditions for utilizing $t$-test formula were actualized as follows:

Randomization of sampling: The study sample was randomly chosen and assigned to the sample of the study of third year primary stage prospective teachers of English, Hurgada Faculty of Education.

Therefore, $t$-test formula was used in the statistical treatment of the study results as follows:

\subsubsection{The Main Research Question}

The main question of the study was stated as follows:

"What is the effectiveness of the proposed program based on using workshops in developing the basic skills of writing skills for third year primary stage prospective teachers of English?"

To answer this question, it was hypothesized that:

"There is a statistically significant difference between the mean scores of the subjects on the basic writing skills knowledge pre-posttest in favour of the post test."

To test this hypothesis, students' scores on the basic writing test were calculated and tabulated .T-test formula for 
independent samples was employed to decide on the significance of the difference between mean scores of the subjects in the pretest and posttest. Table (2) sets out the results of the post-testing of the students' basic writing skills.

Table 2. $t$-test results of pre/post-testing of students' basic writing skills

\begin{tabular}{llllllll}
\hline Subjects & $\begin{array}{l}\text { Number } \\
\text { students }\end{array}$ & of & $\begin{array}{l}\text { Mean } \\
\text { score }\end{array}$ & $\begin{array}{l}\text { Standard } \\
\text { deviation }\end{array}$ & $\begin{array}{l}\text { Observed } \\
t \text {-value }\end{array}$ & $\begin{array}{l}\text { The Effect } \\
\text { Size }\end{array}$ \\
\cline { 1 - 5 } Pretest & 40 & 23.5 & 10.78 & & \multirow{2}{*}{$28.49^{*}$} & 0.976 & \\
\cline { 1 - 6 } Posttest & 40 & 76.75 & 11.67 &
\end{tabular}

$* \mathrm{P} \leq .001$

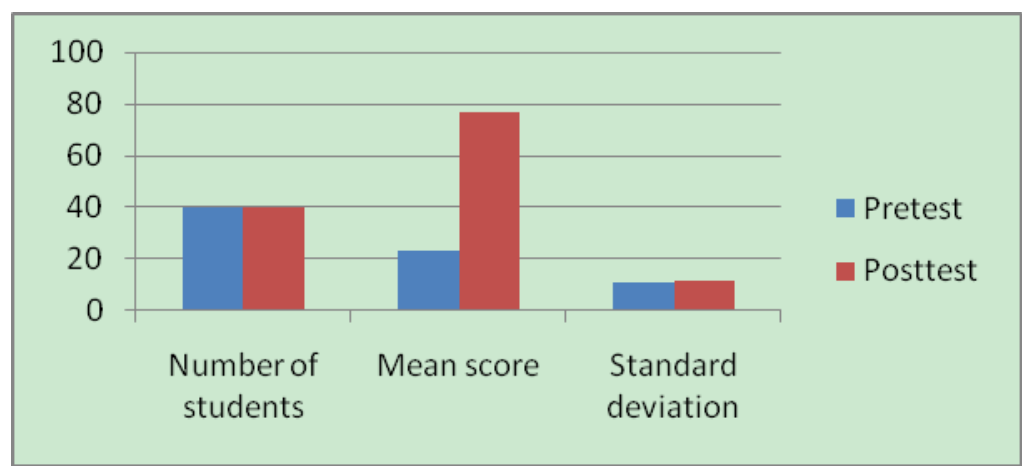

Figure 2. $t$-test results of pre/post-testing of students' basic writing skills

As it is shown in table 2 it is revealed that there is a statistically significant difference between mean scores of the subjects of the study in the pretest and posttest on the basic writing test, favoring the posttest. Therefore, the hypothesis is accepted, i.e. there is a statistically significant difference between mean scores of the subjects in the pretest and posttest on the basic writing posttest in favor of the posttest scores. Since the subjects share all the same variables save the new program, the significant improvement in the subjects' knowledge of the writing skills can be attributed to the effect of the new program. Hence, the writing workshop approach had a significant effect on upgrading the subject's students' basic writing skills.

It is, thus, evident that the new program had a substantial effect on improving the students' basic writing skills. As a result, the first hypothesis; "There is a statistically significant difference between mean scores of the subjects in the pretest and the posttest on the basic writing test. This difference is in favor of the posttest scores." is accepted.

The in-depth analysis of the pre-post test results shows the effectiveness of the four components that constitute the test. In the following few lines, the researcher will shed the light on the four main parts of the test and the statistical treatment. From the previous main question four questions derived as follows:

1. What is the effectiveness of the proposed program based on using workshops in developing the process writing for the third year primary stage prospective Teachers of English?

2. What is the effectiveness of the proposed program based on using workshops in developing punctuation for the third year primary stage prospective Teachers of English?

3. What is the effectiveness of the proposed program based on using workshops in developing spelling for the third year primary stage prospective Teachers of English?

\subsubsection{Research Question One}

The first question of the study was stated as follows:

"What is the effectiveness of the proposed program based on using workshops in developing the "process of writing" for the third year primary stage prospective teachers of English?"

To answer this question, it was hypothesized that: 
There is a statistically significant difference between the mean scores of the subjects on the "process writing" pre-posttest in favor of the posttest.

Table 3 sets out the results of analyzing students' scores on "writing process"

Table 3. $t$-test results of students' scores on the "writingprocess"

\begin{tabular}{|c|c|c|c|c|c|c|c|}
\hline Subjects & $\begin{array}{l}\text { Number } \\
\text { students }\end{array}$ & of & $\begin{array}{l}\text { Mean } \\
\text { score }\end{array}$ & $\begin{array}{l}\text { Standard } \\
\text { deviation }\end{array}$ & $\begin{array}{l}\text { Observed } \\
t \text {-value }\end{array}$ & $\begin{array}{l}\text { The } \\
\text { Size }\end{array}$ & Effect \\
\hline Pretest & 40 & & 5.4875 & 2.57 & & & \\
\hline Posttest & 40 & & 20.6625 & 2.13 & $30.0331 *$ & 0.979 & \\
\hline
\end{tabular}

$* \mathrm{P} \leq .001$

As it is shown in table 3 it is revealed that there is a statistically significant difference between mean scores of the subjects of the study on the pre and posttest on the first component of the writing performance test favoring the post testing. This indicates that the subjects benefited from the new program concerning the "writing process" component. Therefore, the hypothesis is accepted, i.e. there is a statistically significant difference between mean scores of the subjects in the process writing in Pre-posttest on the basic writing skills test in favor of the posttest.

\subsubsection{Research Question Two}

The second question of the study was stated as follows:

What is the effectiveness of the proposed program based on using workshops in developing "punctuation" for the third year primary stage prospective teachers of English?

To answer this question, it was hypothesized that:

There is a statistically significant difference between the mean scores of the subjects on the "punctuation" component in the basic writing skills pre-posttest in favour of the posttest.

Table 4 sets outs the results of analyzing students' scores concerning using punctuation rules.

Table 4. $t$-test results of students' scores on the "punctuation"

\begin{tabular}{cllllll}
\hline Subjects & $\begin{array}{l}\text { Number } \\
\text { students }\end{array}$ & of & Mean score & $\begin{array}{l}\text { Standard } \\
\text { deviation }\end{array}$ & $\begin{array}{l}\text { Observed } \\
t \text {-value }\end{array}$ & $\begin{array}{l}\text { The Effect } \\
\text { Size }\end{array}$ \\
\cline { 1 - 4 } Pretest & 40 & 4.075 & 2.66 & & \\
\cline { 1 - 5 } Posttest & 40 & 21.3875 & 3.41 & $27.599 *$ & 0.975 \\
\hline
\end{tabular}

$* \mathrm{P} \leq .001$

It is clear from the data represented in table (4) that there is a statistically significant difference between mean scores of the subjects of the study in the pretest and posttest on the second component "punctuation" of the writing test. This difference is in favor of the post test scores. This indicates that the new program was beneficial to the subjects concerning the "punctuation" component. Therefore, the hypothesis is accepted, i.e. there is a statistically significant difference between mean scores of the subjects in the pretest and posttest on the second component of the basic writing test in favor of the posttest.

\subsubsection{Research Question Three}

The third question of the study was stated as follows:

What is the effectiveness of the proposed program based on using workshops in developing "spelling" for the third year primary stage prospective teachers of English?

To answer this question, it was hypothesized that:

There is a statistically significant difference between the mean scores of the subjects of the study on the "spelling" component of the basic writing skills pre-posttest in favour of the posttest. 
Table 5 sets outs the results of analyzing students' scores on the third component of the writing performance test concerning the use of Spelling.

Table 5. $t$-test results of students' scores on the "Spelling "component of the writing test

\begin{tabular}{llllllll}
\hline Subjects & $\begin{array}{l}\text { Number } \\
\text { students }\end{array}$ & of & $\begin{array}{l}\text { Mean } \\
\text { score }\end{array}$ & $\begin{array}{l}\text { Standard } \\
\text { deviation }\end{array}$ & $\begin{array}{l}\text { Observed } \\
\text {-value }\end{array}$ & $\begin{array}{l}\text { The } \\
\text { Size }\end{array}$ & Effect \\
\hline Pretest & 40 & 6.7 & 4.79 & $13.6486^{*}$ & & \\
\hline Posttest & 40 & 17.1125 & 4.24 & & 0.909 & \\
\hline
\end{tabular}

$* \mathrm{P} \leq .001$

It is clear from the data represented in table 5 that there is a statistically significant difference between mean scores of the subjects' pre-posttest scores on the third component of the writing performance test. This difference is in favor of the post testing. This indicates that the new program was beneficial to the subjects of the study concerning the "Spelling" component. Therefore, the hypothesis is accepted, i.e. there is a statistically significant difference between mean scores of the subjects of the study in the pretest and posttest on the "spelling" component of the basic writing skills test in favor of the posttest.

\section{Discussion}

It is clear from the in-depth analysis of students' scores on the four components of the basic writing skills test that all components considered in the study have improved significantly as a result of using the writing workshop approach. Observed $t$-values of the whole test as well as of all four components are significantly greater than the tabular $t$-values, indicating that there are significant differences between mean scores of the subjects of the study in the pre and posttest. All differences are in favor of the subjects of the study post test scores.

These results cope with the study conducted by Coleman (2000) which investigated the implementation of a writer's workshop in a primary grade classroom. Results indicated that students responded positively to the implementation of a writer's workshop and their writing skills improved.

The results of the current study also agree with the results of a study conducted by Aly (2002) to investigate the effect of using the writing workshop approach on developing student teachers' composing skills at the English department, Faculty of Education, Ain Shams University. The findings of the study showed that the writing workshop approach helps the students to improve their writing in terms of the writing production skills, i.e. content/organization styles, usage and mechanics. So this study is similar to the present study in the aims and sample yet they are different as the present study aimed at developing basic writing skills whereas Aly's study dealt with composing skills in general. Also, the present study was done in Upper Egypt whereas in Ain Shams university.

Similar results were also found by Agesilas (2003) who conducted a study to investigate the effectiveness of the writing workshop model in improving ESL college students' writing skills. He found that the writing workshop model improved the students' writing skills.

Results of the current study concur with the results of a study conducted by Agesilas (2003) to test the effectiveness of the writing workshop model in improving English-as-a-second-language (ESL) college students' writing skills. Results showed that the students acknowledged that the writing workshop had helped them to better understand the writing process. Students perceived classroom environment, peer response, collaborative writing and speaking as components that helped them the most in improving their writing skills.

The current study benefited greatly from and concurred with the results of El Said (2006) study which investigated the effects of using a program based on the writing workshop approach on developing the writing skills and minimizing the writing apprehension of second-year prep students in Upper Egypt. Results indicated that the writing workshop-based program had significant effects on improving the subjects' knowledge of writing skills, upgrading their writing performance, and minimizing their writing apprehension as compared to the control group student.

Also, the students demonstrated significant improvement in the punctuation area. This improvement can be attributed to the new program as well. The participants were given information about the different punctuation scores, certain defaults in punctuation were presented to be eliminated such as eliminating run-on sentences, sentence fragments and rambling sentences. Providing the students with information about these patterns of 
order was not yet sufficient to attribute this improvement to the new program. This information was followed by many chances for real application and experimentation with every pattern of punctuation. This, of course, was done through the multiple and varied activities contained in the program. Thus, the systematic training in punctuation included throughout the program was a rich experience for the participants to receive practice in this area.

The third component handled in this question is spelling. Also, the participants manifested significant gains in spelling. These gains can be attributed to the activities of the new program. Because of the importance of spelling in writing in general, the researcher paid due focus to this area. For example, the participants were instructed in using spelling rules to ensure correct spelling of words. Furthermore, the Student's Workbook was provided with a supplementary material that included the most important spelling rules students were likely to need in different patterns of writing. Students were also encouraged throughout the program to consult their group peers and their teacher concerning the use of prefixes, suffixes and roots as well as the difference between homophones, homonyms and homographs. All these features empowered them with a reasonable amount of vocabulary items which enriched their writings. Therefore, the improvement taking place in the spelling component can be attributed to the effectiveness of the new program.

\section{Conclusions}

The results of this study can be attributed to the effectiveness of the writing workshops in developing the students' writing abilities. This effectiveness is the result of many aspects of the proposed methodology that are absent in the Egyptian context. These aspects were represented in the features of the new program that contributed to developing basic writing skills of the students. For instance, the systematic instruction provided in the program had a substantial effect on the quality of writing. In addition, the help provided by the teacher during the sessions time and the exchanges that took place between the teacher and the students as well as among the students themselves were influential in improving students' writing. Furthermore, the classroom environment as a whole was of a crucial importance in improving the students' writings.

The in-depth analysis of basic writing components revealed that there are significant differences between the subjects in the pre and posttest. These differences are in favor of the subject's post test scores in all components. As for the process writing component, the subjects exhibited a significant gain in the content area. This gain in this area might be attributed to the systematic instruction and training in observation skills. The participants were trained in using the various writing stages and also using each stage techniques as the prewriting techniques. Also, those students were provided with many chances in which they experienced with varied topics, both pre assigned topics and topics of their own choice. Moreover, the ideas-generation techniques, such as brainstorming, free writing, and journalist's questions, were very effective in providing the students with the required details. Furthermore, the concentration of the researcher throughout the different stages of each session on the idea that students can benefit from each other and add to or improve their ideas at any stage resulted in the overall richness of the content of their pieces. For all these reasons, the gain in the process writing area can be attributed to the new program.

\section{Recommendations}

Based on the findings of the present study, the researcher recommends introducing the writing workshop approach to be used in teaching writing in faculties of Education. It is also recommended that giving due focus to the process writing approach to writing instruction and training students as well as teachers of English on using that approach. In addition, based on the results of the study we should introduce the notion of peer and group work into writing classes instead of the traditional view of writing as an individual activity. This entails training the students to work collaboratively with each other when writing. The writing class environment should be centered on the student rather than the teacher. In other words, when students begin to write, what the students themselves know should be stressed and teacher intervention should be kept minimal. The researcher also recommends introducing other forms of evaluation, namely self as well as peer evaluation, into writing classes prior to teacher evaluation.

\section{Acknowledgement}

All thanks goes to Dr. Antar Solhy, Associate professor of TEFL, Taiba University. Also, my gratitude for Dr. Azza Marsfy, professor of TEFL, Zagazig University. A big thank you for Dr. Ali Madkour, Professor of Arabic Language Teaching, Cairo University.Due thanks goes to Dr. Elham Abdulhameed, professor of Curricula and Instruction, Cairo University. The biggest thank you goes to Dr. Mahmoud Al-Naka, Professor of Arabic Language Teaching, Ain Shams University. Many thanks go to my dear colleagues in the State of Kuwait. Many thanks go to my mother, wife, and daughters Malak and Nour. 


\section{References}

Abolyosr, M. (1996). Designing a Program for Developing the Writing Skill: an Integrative-Interactive Approach. Unpublished PhD thesis. Qena Faculty of Education. South Valley University.

Al-Saleem, A. A. (2008). The Effect of the Whole Language Approach on Developing English Writing Skills for the First Year Secondary School Students in Saudi Arabia. Unpublished Ph.D. Thesis.Cairo University. Egypt.

Byrne, D. (1993). Techniques for Classroom Interaction. Longman: London.

El Said, A. M., (2006). The Effect of Using A programme Based on the Writing Workshop Approach on the Writing skills and on the writing Apprehension of the second year Preparatory Student. Unpublished MA. Sohag Faculty of Education, South Valley University.

Elizabeth, M. (2004). Methods of Teaching English. New Delhi, India: Discovery Publishing House.

Harris, Theodore L., \& Hodges, Richard, E. (1995). The Literary Dictionary: The Vocabulary of Reading and Writing. The International Reading Association, Inc.

Heaton J. B. (1994). Writing English Language Tests. Longman Inc. New York.

Helal, E. A. A. (2003). A proposed self-Access Reading Program for Developing English Language Writing Skills for First Year Secondary Students. M.A. Thesis. Ain Shams University, Egypt.

Kieczykowski, Carol. (1996). Primary writer's Workshop: Developing Process Writing Skills. New Jersey: Modern Curriculum Press.

Massengill, M. (2001). Negotiating Transitions at Risk Students Adjustment from a Middle School Reading Workshop to Traditional High School English Class. DAL, 62(5), 1-16.

Pollington M. F. (1999). Intermediate grader writers' self perception: a comparison of the effect of writing workshop and traditional instruction. DAI, 1(4), 1-7.

Richards, C. R. (1990). The Language Teaching Matrix. Cambridge: Cambridge University Press. http://dx.doi.org/10.1017/CBO9780511667152

Salem, Ashraf Atta M. S. (2008). The Effectiveness of a Proposed Program Based on Using Workshops in Developing the Functional Writing Skills of Primary Stage Prospective Teachers of English. Unpublished MA Thesis in TEFL. Institute of Educational Studies, Cairo University, Egypt.

Stretch, Lorie L. (1994). The Implementation of Writing Workshop: A Review of the Literature. Retrieved from http://www.eric.ed.gov.doi.380797

\section{Copyrights}

Copyright for this article is retained by the author(s), with first publication rights granted to the journal.

This is an open-access article distributed under the terms and conditions of the Creative Commons Attribution license (http://creativecommons.org/licenses/by/3.0/). 